\title{
KAJIAN PERBANDINGAN EFEKTIVITAS TAMSULOSIN, DUTASTERIDE DAN KOMBINASINYA PADA PASIEN BPH DI RSUD GUNUNG JATI CIREBON
}

\author{
COMPARATIVE STUDY OF THE EFFECTIVENESS OF \\ TAMSULOSIN, DUTASTERIDE AND THE COMBINATION IN \\ PATIENTS WITH BPH IN RSUD GUNUNG JATI CIREBON
}

\author{
Siti Pandanwangi TW ${ }^{1}$, Amirudin ${ }^{2}$ \\ ${ }^{1}$ Akademi Farmasi Muhammadiyah Cirebon \\ ${ }^{2}$ Sekolah Tinggi Farmasi Cirebon \\ Jl. Cideng Indah no.3 Cirebon \\ Email: sitipandanwangitw@yahoo.com
}

\begin{abstract}
ABSTRAK
Kajian perbandingan efektivitas Tamsulosin, Dutasteride dan Kombinasinya pada pasien pembesaran prostat jinak atau BPH (Benign Prostate Hyperplasia) di RSUD. Gunung Jati Cirebon dengan melihat penurunan nilai skor IPSS dan meningkatnya kualitas hidupnya, dengan kriteria usia $\geq 50$ tahun tanpa penyakit penyerta Diabetes Melitus maupun Hipertensi dengan gejala LUTS (Lower Urinary Tract Symptoms) sedang - berat nilai skor IPSS (International Prostatic Symptom Score) 8 - 35 dan berkunjung ke poli Urologi dari Bulan Maret 2016 - Agustus 2016.Jumlah pasien yang diikutkan 42 pasien, dengan bulan Maret Juni 2016 yaitu melihat medical record pasien BPH dan memasukkannya ke nilai IPSS maupun kualitas hidupnya, untuk bulan Juli - Agustus 2016 dengan interview IPSS dan kualitas hidup langsung ke pasiennya.Data yang diperoleh dianalisa menggunakan Chi Square untuk menganalisis perbandingan beberapa kelompok pengobatan terhadap penyembuhan.Pemberian monoterapi Tamsulosin, monoterapi Dutasteride maupun kombinasi Tamsulosin-Dutasteride efektif menurunkan gejala dan meningkatkan kualitas hidup pasien BPH.Pemberian monoterapi Tamsulosin dalam penurunan rata-rata IPSS pasien BPH adalah 1.985 ; Dutasteride 0.748 ; dan kombinasi Tamsulosin-Dutasteride 3.245. Pemberian monoterapi Tamsulosin dalam penurunan rata-rata kualitas hidup pasien BPH 3.109 ; Dutasteride 3.276 ; dan kombinasi Tamsulosin-Dutasteride adalah 2.853 sehingga peningkatan kualitas hidup terapi kombinasi lebih baik dibandingkan masingmasing monoterapi karena mempunyai nilai yang lebih kecil.
\end{abstract}

Kata Kunci: Tamsulosin, Dutasteride, Terapi Kombinasi, BPH (Benign Prostate Hyperplasia)

\begin{abstract}
A comparative study of the effectiveness of Tamsulosin, Dutasteride and Combination in patients of benign prostate enlargement or BPH (Benign Prostate Hyperplasia) in the RSUD. Gunung Jati Cirebon with respect IPSS score values decline and increasing quality of life, with the criteria of age $\geq 50$ years without a companion disease Diabetes mellitus or Hypertension with LUTS (Lower Urinary Tract Symptoms) the symptoms are - the weight value score IPSS (International Prostatic Symptom Score) 8 - 35 and pay a visit to the Urology Poly RSUD. Gunung Jati Cirebon from March 2016 - August 2016.On the research of the number of patients included 48 patients, with repro March - June 2016 that is looking
\end{abstract}


at the medical records of the patient's BPH and put it to the value of quality of life, as well as the IPSS for July - August 2016 interview with IPSS and quality of life directly to his patients.From the results of the research are all proven to reduce symptoms and improve the quality of life, but only the combination of Tamsulosin+Dutasteride that are far better than the respective monoterapi Tamsulosin or Dutasteride. It can be concluded that the combination of Tamsulosin+Dutasteride is more effective in decreasing the symptoms of $\mathrm{BPH}$ patients and quality of life than the respective monoterapi.

Keywords: Tamsulosin, Dutasteride, Combine Therapy, BPH (Benign Prostate Hyperplasia)

\section{PENDAHULUAN}

Lanjut usia pada umumnya mengalami perubahan-perubahan pada jaringan tubuh, yang disebabkan oleh prosespenuaan dan degenerasi pada organ-organ tubuh, khususnya sistem traktus urinarius. Kondisi ini dapat mengganggu aktifitas sehari-hari pada lansia yang berdampak pada penurunan kualitas hidup.

Kelenjar prostat adalah salah satu organ tubuh pria khususnya pada lansia, yang paling sering mengalami gangguan, yaitu pembesaran prostat jinak atau Benign Prostate Hyperplasia yang selanjutnya disingkat BPH. Dalam hal ini kelenjar periuretra mengalami pembesaran, sedangkan jaringan prostat asli terdesak ke perifer menjadi kapsul. BPH akan muncul seiring dengan bertambanya usia.

Penyakit pembesaran prostat jinak menjadi urutan kedua penyakit tersering, setelah penyakit batu saluran kemih yang sering dijumpai di klinik urologi Indonesia. Secara umum, $5 \%$ atau sekitar 5 juta dari jumlah pria di Indonesia sudah masuk ke dalam kelompok usia 60 tahun ke atas, dan dinyatakan bahwa sekitar 2,5 juta pria Indonesia menderita penyakit BPH.

LUTS (Lower Urinary Tract Symptoms) adalah istilah umum untuk menjelaskan berbagai gejala berkemih yang dikaitkan dengan BPH (Benign Prostate Hyperplasia). Keluhan pasien BPH berupa LUTS terdiri atas gejala obstruksi (voiding symptoms) maupun iritasi (storage symptoms). Pasien BPH biasanya mengalami keluhan berkemih, penderita melaporkan frekuensi berkemih meningkat, khususnya pada malam hari, bahkan ada kalanya tidak dapat ditahan (urgency) yang dapat mengakibatkan terjadinya incontinencia. Selain itu pasien juga sering melaporkan perasaan tidak puas setelah berkemih. Bila hambatan pada uretra terus meningkat, berkemih akan makin sulit dan pancaran berkemih juga melemah, bahkan berkemih dapat mendadak berhenti.

Tamsulosinbekerja dengan memblokade reseptor $\alpha 1$-adrenergik sehingga menyebabkan relaksasi otot polos pembuluh darah. Reseptor $\alpha 1$-adrenergik juga menyebabkan kontraksi otot di prostat dan kandung kemih. Efek memblokade reseptor akan menyebabkan relaksasi otot di prostat dan kandung kemih.

Dutasteride bekerja dengan menghambat pembentukan DHT (dihidrotestosteron) dari testosteron yang dikatalisis oleh enzim $5 \alpha$-reductase di dalam sel prostat. Penurunan kadar DHT (dihidrotestosteron) akan menurunkan pula sintesis protein dan replikasi sel-sel prostat. Sehingga 5ARI (5a-Reductase Inhibitor) efektif untuk mengobati gejala yang disebabkan oleh BPH dan menurunkan volume prostat, dan Dutasteride ini merupakan 5ARI (5a-Reductase Inhibitor) yang menghambat enzim 5 $\alpha$-reductase type 1 dan type 2 sehingga penekanan DHT (dihidrotestosteron) nya lebih baik.

Tujuan dari penelitian ini untuk mengetahui efektivitas pemberian Tamsulosin, Dutasteride dan Kombinasinya terhadap penurunan gejala dan meningkatkan kualitas hidup pasien BPH, untuk mengetahui efektivitas rata-rata penurunan nilai IPSS (International Prostatic Symptom Score), mengetahui efektivitas rata-rata penurunan nilai kualitas hidup, mengetahui mana yang memiliki efektivitas yang lebih baik. 


\section{METODE PENELITIAN}

\section{Bahan}

Penelitian ini menggunakan desain penelitian metode Quasi Eksperimen. Penelitian yang memiliki perlakuan (treatment), pengukuran - pengukuran dampak (outcome measures), dan unit - unit eksperiment (experimental units) namun tidak menggunakan penempatan secara acak.

Populasi dalam penelitian ini adalah pasien telah terdiagnosa menderita BPH yangberusia $\geq 50$ tahun dan tanpa penyakit penyerta Diabetes Melitus maupun Hipertensi dengan gejala LUTS (Lower Urinary Tract Symptoms) sedang - berat nilai skor IPSS (International Prostatic Symptom Score) 8 - 35, pasien berkunjung ke poli Urologi RSUD. Gunung Jati Cirebon dari Bulan Maret 2016 - Agustus 2016, pasien mendapatkan obat monoterapi Tamsulosin atau monoterapi Dutasteride atau kombinasi TamsulosinDutasteride. Dalam hal ini populasi berjumlah 72 pasien.

Dari perhitungan sampel menggunakan rumus slovin, maka sampel yang diteliti adalah 42 pasien, dengan rincian, monoterapi Tamsulosin sebanyak 14 pasien, monoterapi Dutasteride sebanyak 14 pasien, kombinasi Tamsulosin-Dutasteride sebanyak 14 pasien.

Alat

Alat peneltian yang digunakan adalah medical record, format nilai atau skor IPSS.

\section{Jalannya Penelitian}

Jalan penelitian ini dengan cara mengelompokkan pasien-pasien yang diterapi dengan Tamsulosin, Dutasteride, dan kombinasi Tamsulosin-Dutasteride. Kemudian melakukan wawancara dengan pasien, apa yang dirasakan pasien setelah diterapi dengan Tamsulosin, Dutasteride dan kombinasi Tamsulosin-Dutasteride yang dibantu dengan pengisian IPSS (International Prostatic Symptom Score) dan kualitas hidupnya. Setelah diperoleh hasil wawancara dengan pasien BPH(Benign Prostate Hyperplasia), peneliti menjumlah dan mencatat nilai skor yang dihasilkan dari IPSS dan kualitas hidupnya.

\section{Analisa Data}

Analisis Chi Square adalah salah satu jenis uji komparatif non parametris yang dilakukan pada dua variabel, di mana skala data kedua variabel adalah nominal. (Apabila dari 2 variabel, ada 1 variabel dengan skala nominal maka dilakukan uji chi square dengan merujuk bahwa harus digunakan uji pada derajat yang terendah). 


\section{HASIL DAN PEMBAHASAN}

Dalam penelitian ini pada bulan Maret-Juni 2016 (retrospektif) melihat gejala pasien dengan alat bantu kuisioner IPSS (International Prostatic Symptom Score) dari medical record :

\section{Tabel 1Pasien BPH Terapi Tamsulosin}

\begin{tabular}{ccccl}
\hline No. & Medrec & Nama Pasien & Tahun & \multicolumn{1}{c}{ Alamat } \\
\hline 1 & 415332 & $\mathrm{~T}-1$ & 77 & Cirebon \\
2 & 814866 & $\mathrm{~T}-2$ & 72 & Tengahtani \\
3 & 908077 & $\mathrm{~T}-3$ & 74 & Pabuaran \\
4 & 901410 & $\mathrm{~T}-4$ & 65 & Sumber \\
5 & 901622 & $\mathrm{~T}-5$ & 63 & Cirebon \\
6 & 907266 & $\mathrm{~T}-6$ & 54 & Sumber \\
7 & 897933 & $\mathrm{~T}-7$ & 55 & Kertawinangun \\
8 & 897965 & $\mathrm{~T}-8$ & 74 & Gn Jati Cirebon \\
9 & 908739 & $\mathrm{~T}-9$ & 62 & Kedawung \\
10 & 901976 & $\mathrm{~T}-10$ & 60 & Sumber \\
11 & 852830 & $\mathrm{~T}-11$ & 62 & Harjamukti Cirebon \\
12 & 796606 & $\mathrm{~T}-12$ & 70 & Kedawung \\
13 & 836486 & $\mathrm{~T}-13$ & 56 & Harjamukti Cirebon \\
14 & 470364 & $\mathrm{~T}-14$ & 68 & Kalitanjung \\
\hline
\end{tabular}

sedangkan pada bulan Juli-Agustus 2016 (prospektif) menggunakan interview ke pasien langsung dan dibantu dengan perawat poli urologi dengan penilaian skor IPSS yang terdiri dari 7 pertanyaan tentang gejala yang dirasakan dan 1 pertanyaan tentang kualitas hidupnya, dari hasil penelitian didapat hasil :

Tabel 2 Hasil IPSS Pasien Dengan Terapi Tamsulosin

\begin{tabular}{ccccccc}
\hline \multirow{2}{*}{ Pasien } & \multicolumn{6}{c}{ Bulan } \\
& Maret & April & Mei & Juni & Juli & Agustus \\
\hline $\mathrm{T}-1$ & 20 & 15 & 12 & 9 & 6 & 5 \\
$\mathrm{~T}-2$ & 18 & 15 & 11 & 9 & 5 & 4 \\
$\mathrm{~T}-3$ & 21 & 16 & 13 & 10 & 6 & 5 \\
$\mathrm{~T}-4$ & 19 & 16 & 14 & 11 & 7 & 6 \\
$\mathrm{~T}-5$ & 21 & 17 & 15 & 11 & 6 & 5 \\
$\mathrm{~T}-6$ & 22 & 16 & 12 & 9 & 7 & 4 \\
$\mathrm{~T}-7$ & 20 & 14 & 13 & 10 & 7 & 5 \\
$\mathrm{~T}-8$ & 19 & 12 & 10 & 8 & 7 & 6 \\
$\mathrm{~T}-9$ & 21 & 16 & 13 & 9 & 6 & 4 \\
$\mathrm{~T}-10$ & 20 & 18 & 15 & 12 & 8 & 6 \\
$\mathrm{~T}-11$ & 20 & 17 & 14 & 11 & 7 & 5 \\
$\mathrm{~T}-12$ & 21 & 17 & 13 & 10 & 7 & 5 \\
$\mathrm{~T}-13$ & 19 & 14 & 11 & 9 & 6 & 4 \\
$\mathrm{~T}-14$ & 19 & 13 & 11 & 9 & 7 & 5 \\
\hline
\end{tabular}

Nilai skor 0-7 :gejala ringan, nilai skor 8-19 : gejala sedang, nilai skor 20-35 : gejala berat 
Tabel 3. Hasil Kualitas Hidup Pasien Dengan Terapi Tamsulosin

\begin{tabular}{|c|c|c|c|c|c|c|}
\hline \multirow{2}{*}{ Pasien } & \multicolumn{6}{|c|}{ Bulan } \\
\hline & Maret & April & Mei & Juni & Juli & Agustus \\
\hline $\mathrm{T}-1$ & 6 & 5 & 5 & 4 & 3 & 2 \\
\hline $\mathrm{T}-2$ & 6 & 5 & 5 & 4 & 3 & 2 \\
\hline $\mathrm{T}-3$ & 6 & 6 & 5 & 4 & 3 & 2 \\
\hline $\mathrm{T}-4$ & 6 & 6 & 5 & 4 & 4 & 1 \\
\hline$T-5$ & 6 & 6 & 5 & 4 & 3 & 1 \\
\hline$T-6$ & 6 & 6 & 5 & 4 & 2 & 1 \\
\hline $\mathrm{T}-7$ & 6 & 5 & 5 & 4 & 3 & 2 \\
\hline $\mathrm{T}-8$ & 6 & 5 & 5 & 4 & 2 & 2 \\
\hline $\mathrm{T}-9$ & 6 & 6 & 4 & 3 & 4 & 2 \\
\hline $\mathrm{T}-10$ & 6 & 6 & 5 & 4 & 3 & 1 \\
\hline $\mathrm{T}-11$ & 6 & 6 & 5 & 4 & 3 & 2 \\
\hline $\mathrm{T}-12$ & 6 & 6 & 4 & 4 & 4 & 2 \\
\hline $\mathrm{T}-13$ & 6 & 5 & 5 & 4 & 3 & 1 \\
\hline $\mathrm{T}-14$ & 6 & 5 & 5 & 3 & 2 & 1 \\
\hline
\end{tabular}

Darihasil analisa data menggunakan Chi Square diperoleh nilai Chi Square 6,4 melebihi harga tabel, dan nilai signifikansi 0,11. Nilai signifikansi $<0,05$ memiliki arti adanya pengaruh pemberian tampsulosin terhadap penurunan nilai IPSS selama 6 bulan. Selain itu dari hasil analisa data tabel kualitas hidup diperoleh nilai Chi Square 4,455 dan nilai signifikansi 0,035 artinyaadanya peningkatan kualitas hidup pasien BPH selama pemberian tampsulosin.

\subsubsection{Pasien BPH Terapi Dutasteride}

Dalam penelitian ini pada Bulan Maret - Juni 2016 (retrospektif) melihat gejala pasien dengan alat bantu kuisioner IPSS (International Prostatic Symptom Score) dari medical record :

Tabel 4

Pasien BPH Terapi Dutasteride

\begin{tabular}{ccccl}
\hline No. & Medrec & Nama Pasien & Tahun & \multicolumn{1}{c}{ Alamat } \\
\hline 1 & 907163 & D -1 & 75 & Dawuan \\
2 & 904625 & D -2 & 67 & Mundu \\
3 & 853880 & D -3 & 66 & Adidarma Cirebon \\
4 & 834110 & D -4 & 60 & Harjamukti Cirebon \\
5 & 805248 & D -5 & 63 & Kejaksan \\
6 & 896268 & D -6 & 62 & Cirebon \\
7 & 892522 & D -7 & 75 & Talun Cirebon \\
8 & 416686 & D -8 & 70 & Plered \\
9 & 908513 & D -9 & 60 & Greged Cirebon \\
10 & 909081 & D -10 & 84 & Pasindangan \\
11 & 908698 & D -11 & 73 & Indramayu \\
12 & 883256 & D -12 & 55 & Bongas Kulon \\
13 & 611096 & D -13 & 55 & Leuwimunding \\
14 & 696789 & D -14 & 64 & Kalitanjung \\
\hline
\end{tabular}


sedangkan pada bulan Juli - Agustus 2016 (prospektif) menggunakan interview ke pasien langsung dengan penilaian skor IPSS yang terdiri dari 7 pertanyaan tentang gejala yang dirasakan dan 1 pertanyaan tentang kualitas hidupnya, dari hasil penelitian didapat hasil :

Tabel 5. Hasil IPSS Pasien Dengan Terapi Dutasteride

\begin{tabular}{|c|c|c|c|c|c|c|}
\hline \multirow{2}{*}{ Pasien } & \multicolumn{6}{|c|}{ Bulan } \\
\hline & Maret & April & Mei & Juni & Juli & Agustus \\
\hline $\mathrm{D}-1$ & 20 & 17 & 15 & 13 & 11 & 9 \\
\hline$D-2$ & 18 & 16 & 14 & 12 & 11 & 10 \\
\hline$D-3$ & 19 & 16 & 14 & 13 & 12 & 9 \\
\hline$D-4$ & 22 & 20 & 17 & 15 & 13 & 11 \\
\hline$D-5$ & 18 & 14 & 12 & 11 & 11 & 9 \\
\hline$D-6$ & 20 & 18 & 16 & 14 & 12 & 10 \\
\hline $\mathrm{D}-7$ & 22 & 17 & 16 & 15 & 13 & 11 \\
\hline $\mathrm{D}-8$ & 21 & 16 & 14 & 11 & 10 & 9 \\
\hline $\mathrm{D}-9$ & 19 & 17 & 15 & 13 & 12 & 11 \\
\hline$D-10$ & 19 & 16 & 13 & 11 & 10 & 9 \\
\hline $\mathrm{D}-11$ & 22 & 18 & 15 & 13 & 11 & 9 \\
\hline$D-12$ & 19 & 17 & 16 & 15 & 13 & 10 \\
\hline $\mathrm{D}-13$ & 20 & 18 & 15 & 13 & 12 & 10 \\
\hline$D-14$ & 21 & 18 & 16 & 15 & 13 & 9 \\
\hline
\end{tabular}

Tabel 6. Hasil Kualitas Hidup Pasien Dengan Terapi Dutasteride

\begin{tabular}{|c|c|c|c|c|c|c|}
\hline \multirow{2}{*}{ Pasien } & \multicolumn{6}{|c|}{ Bulan } \\
\hline & Maret & April & Mei & Juni & Juli & Agustus \\
\hline $\mathrm{D}-1$ & 6 & 6 & 5 & 5 & 3 & 2 \\
\hline $\mathrm{D}-2$ & 6 & 6 & 5 & 5 & 3 & 2 \\
\hline $\mathrm{D}-3$ & 6 & 6 & 5 & 5 & 4 & 3 \\
\hline $\mathrm{D}-4$ & 6 & 6 & 5 & 5 & 4 & 3 \\
\hline$D-5$ & 6 & 6 & 5 & 5 & 4 & 3 \\
\hline$D-6$ & 6 & 6 & 5 & 5 & 4 & 3 \\
\hline $\mathrm{D}-7$ & 6 & 6 & 5 & 5 & 4 & 3 \\
\hline $\mathrm{D}-8$ & 6 & 6 & 5 & 4 & 4 & 3 \\
\hline$D-9$ & 6 & 6 & 5 & 5 & 3 & 3 \\
\hline$D-10$ & 6 & 6 & 5 & 4 & 3 & 3 \\
\hline$D-11$ & 6 & 6 & 5 & 5 & 4 & 4 \\
\hline$D-12$ & 6 & 6 & 5 & 5 & 4 & 4 \\
\hline $\mathrm{D}-13$ & 6 & 6 & 5 & 5 & 4 & 3 \\
\hline$D-14$ & 6 & 6 & 5 & 5 & 4 & 3 \\
\hline
\end{tabular}

Dari hasil analisa data menggunakan Chi Square diperoleh nilai Chi Square 4,5 melebihi harga tabel, dan nilai signifikansi 0,034. Nilai signifikansi $<0,05$ memiliki arti adanya pengaruh pemberian dutasterid terhadap penurunan nilai IPSS selama 6 bulan. Selain itu dari hasil analisa data tabel kualitas hidup diperoleh nilai Chi Square 4,455 dan nilai signifikansi 0,035 artinyaadanya peningkatan kualitas hidup pasien BPH selama pemberian dutasterid. 


\subsubsection{Pasien BPH Terapi Kombinasi Tamsulosin-Dutasteride}

Dalam penelitian ini pada Bulan Maret - Juni 2016 (retrospektif) melihat gejala pasien dengan alat bantu kuisioner IPSS (International Prostatic Symptom Score) dari medical record :

Tabel 7. Pasien BPH Terapi Kombinasi Tamsulosin-Dutasteride

\begin{tabular}{ccccl}
\hline No. & Medrec & Nama Pasien & Tahun & \multicolumn{1}{c}{ Alamat } \\
\hline 1 & 907693 & $\mathrm{~K}-1$ & 53 & Kedawung \\
2 & 908596 & $\mathrm{~K}-2$ & 54 & Majalengka \\
3 & 911360 & $\mathrm{~K}-3$ & 55 & Talaga Majalengka \\
4 & 912253 & $\mathrm{~K}-4$ & 68 & Kuningan \\
5 & 898925 & $\mathrm{~K}-5$ & 60 & Cirebon \\
6 & 901611 & $\mathrm{~K}-6$ & 74 & Tengahtani \\
7 & 906630 & $\mathrm{~K}-7$ & 83 & Majalengka \\
8 & 730710 & $\mathrm{~K}-8$ & 70 & Suranenggala \\
9 & 844532 & $\mathrm{~K}-9$ & 65 & Indramayu \\
10 & 812644 & $\mathrm{~K}-10$ & 66 & Kedawung \\
11 & 842829 & $\mathrm{~K}-11$ & 60 & Kesambi \\
12 & 730344 & $\mathrm{~K}-12$ & 57 & Kejaksan \\
13 & 829703 & $\mathrm{~K}-13$ & 70 & Cirebon \\
14 & 712959 & $\mathrm{~K}-14$ & 65 & Kedawung \\
\hline
\end{tabular}

sedangkan pada bulan Juli - Agustus 2016 (prospektif) menggunakan interview ke pasien langsung dengan penilaian skor IPSS yang terdiri dari 7 pertanyaan tentang gejala yang dirasakan dan 1 pertanyaan tentang kualitas hidupnya, dari hasil penelitian didapat hasil :

Tabel 8. Hasil IPSS Pasien Dengan Terapi Kombinasi Tamsulosin-Dutasteride

\begin{tabular}{ccccccc}
\hline \multirow{2}{*}{ Pasien } & Maret & April & Mei & Juni & Juli & Agustus \\
\hline $\mathrm{K}-1$ & 22 & 15 & 7 & 4 & 2 & 1 \\
$\mathrm{~K}-2$ & 20 & 14 & 8 & 3 & 1 & 0 \\
$\mathrm{~K}-3$ & 19 & 13 & 8 & 5 & 2 & 0 \\
$\mathrm{~K}-4$ & 21 & 15 & 8 & 4 & 3 & 1 \\
$\mathrm{~K}-5$ & 18 & 13 & 7 & 3 & 1 & 0 \\
$\mathrm{~K}-6$ & 19 & 11 & 9 & 5 & 3 & 1 \\
$\mathrm{~K}-7$ & 20 & 14 & 10 & 3 & 2 & 0 \\
$\mathrm{~K}-8$ & 21 & 12 & 8 & 2 & 1 & 0 \\
$\mathrm{~K}-9$ & 19 & 14 & 8 & 2 & 1 & 0 \\
$\mathrm{~K}-10$ & 20 & 14 & 9 & 4 & 3 & 0 \\
$\mathrm{~K}-11$ & 21 & 13 & 7 & 2 & 2 & 0 \\
$\mathrm{~K}-12$ & 21 & 11 & 6 & 3 & 3 & 1 \\
$\mathrm{~K}-13$ & 19 & 12 & 8 & 3 & 2 & 0 \\
$\mathrm{~K}-14$ & 20 & 12 & 9 & 4 & 2 & 0 \\
\hline Nilai skor 0-7 :gejala ringan, nilai skor 8-19: gejala sedang, nilai skor 20-35: gejala berat &
\end{tabular}


Tabel 9. Hasil Kualitas Hidup Pasien Dengan Terapi Kombinasi TamsulosinDutasteride

\begin{tabular}{ccccccc}
\hline \multirow{2}{*}{ Pasien } & Maret & April & Mei & Juni & Juli & Agustus \\
\hline \hline $\mathrm{K}-1$ & 6 & 5 & 4 & 3 & 1 & 1 \\
$\mathrm{~K}-2$ & 6 & 5 & 4 & 3 & 1 & 0 \\
$\mathrm{~K}-3$ & 6 & 5 & 4 & 2 & 1 & 0 \\
$\mathrm{~K}-4$ & 6 & 5 & 4 & 2 & 1 & 1 \\
$\mathrm{~K}-5$ & 6 & 5 & 4 & 3 & 1 & 0 \\
$\mathrm{~K}-6$ & 6 & 5 & 4 & 2 & 1 & 1 \\
$\mathrm{~K}-7$ & 6 & 5 & 4 & 2 & 1 & 0 \\
$\mathrm{~K}-8$ & 6 & 5 & 4 & 3 & 1 & 0 \\
$\mathrm{~K}-9$ & 6 & 5 & 4 & 3 & 1 & 0 \\
$\mathrm{~K}-10$ & 6 & 5 & 4 & 2 & 1 & 0 \\
$\mathrm{~K}-11$ & 6 & 5 & 4 & 2 & 1 & 1 \\
$\mathrm{~K}-12$ & 6 & 5 & 4 & 2 & 1 & 1 \\
$\mathrm{~K}-13$ & 6 & 5 & 4 & 2 & 1 & 0 \\
$\mathrm{~K}-14$ & 6 & 5 & 4 & 2 & 1 & 0 \\
\hline
\end{tabular}

Darihasil analisa data menggunakan Chi Square diperoleh nilai Chi Square 9,143 melebihi harga tabel, dan nilai signifikansi 0,010. Nilai signifikansi $<0,05$ memiliki arti adanya pengaruh pemberian dutasterid terhadap penurunan nilai IPSS selama 6 bulan. Selain itu dari hasil analisa data tabel kualitas hidup diperoleh nilai Chi Square 9,143 dan nilai signifikansi 0,010 artinya adanya peningkatan kualitas hidup pasien BPH selama pemberian dutasterid

\subsubsection{Uji t (Parsial)}

Uji t digunakan untuk mengetahui apakah variabel-variabel independen secara parsial berpengaruh nyata atau tidak terhadap variabel dependen. Dengan nilai signifikan yang digunakan adalah 0,05. Apabila nilai signifikan lebih kecil dari 0,05 maka kita menerima hipotesa alternatif, yang menyatakan bahwa suatu variabel independen secara parsial mempengaruhi variabel dependen.Sehingga terapi Kombinasi Tamsulosin dan Dutasteride adalah terapi yang lebih baik dibandingkan dengan masing-masing monoterapi untuk pasien BPH.

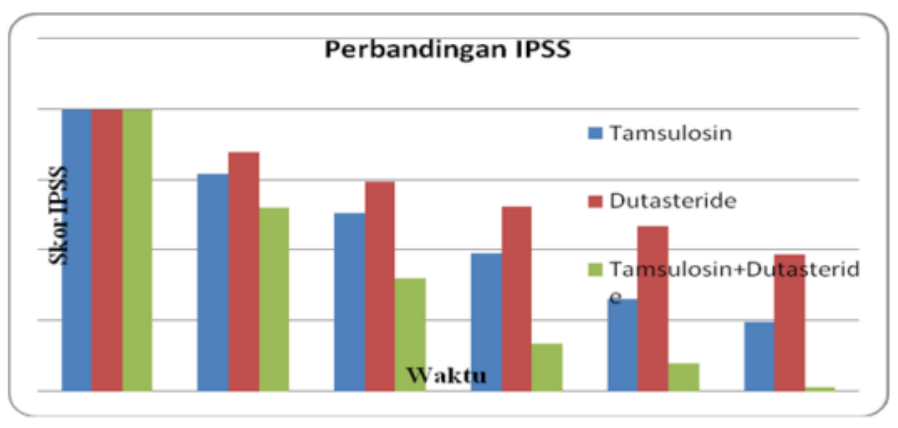

Gambar 4.1 Perbandingan IPSS Terapi Tamsulosin, Dutasteride dan Kombinasinya 
Pada gambar 4.1 menunjukkan bahwa penurunan skor IPSS untuk terapi kombinasi lebih baik daripada masing-masing monoterapi. Hal ini disebabkan pada pemberian kombinasi Tamsulosin+Dutasteride yang kerjanya saling melengkapi, dimana Tamsulosin dengan kerjanya merelaksasi otot polos dan Dutasteride dengan kerjanya menekan DHT (dihidrotestosteron) sehingga menurunkan volume prostat.

\subsubsection{Uji t (Parsial)}

Uji t digunakan untuk mengetahui apakah variabel-variabel independen secara parsial berpengaruh nyata atau tidak terhadap variabel dependen. Dengan nilai signifikan yang digunakan adalah 0,05. Apabila nilai signifikan lebih kecil dari 0,05 maka kita menerima hipotesis alternatif, yang menyatakan bahwa suatu variabel independen secara parsial mempengaruhi variabel dependen.

Sehingga terapi Kombinasi Tamsulosin dan Dutasteride adalah terapi yang lebih baik dalam peningkatan kualitas hidupnya dibandingkan dengan masing-masing monoterapi untuk pasien BPH karena mempunyai nilai lebih kecil dibandingkan dengan masing-masing monoterapi.

\subsubsection{Uji F (Simultan)}

Uji $\mathrm{F}$ digunakan untuk mengetahui apakah variabel-variabel independen secara simultan berpengaruh signifikan terhadap variabel dependen. Dengan nilai derajat kepercayaan yang digunakan adalah 0,05 . Apabila nilai $\mathrm{F}$ perhitungan lebih besar dari nilai $\mathrm{F}$ tabel maka hipotesa alternatif diterima, yang menyatakan bahwa semua variabel independen secara simultan pengaruhnya signifikan terhadap variabel dependen.

Berikut ini merupakan output kualitas hidup dari hasil Uji F :

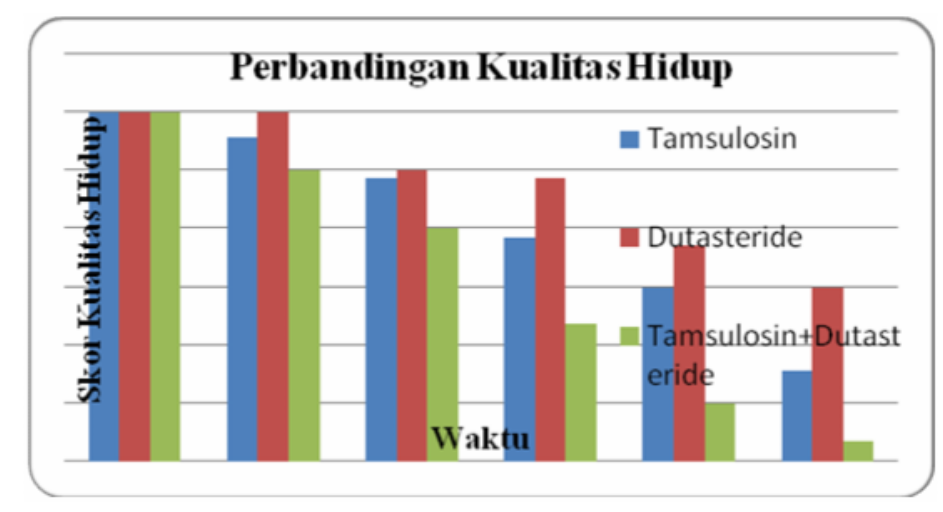

\section{Gambar 4.2 Perbandingan Kualitas Hidup Terapi Tamsulosin, Dutasteride dan Kombinasinya}

Pada gambar 4.2 menunjukkan bahwa rata-rata penurunan skor kualitas hidup untuk terapi kombinasi lebih baik daripada masing-masing monoterapi. Hal ini disebabkan penurunan skor kualitas hidup terapi kombinasi lebih tinggi dari masing-masing monoterapi dan pemberian kombinasi Tamsulosin+Dutasteride yang kerjanya saling melengkapi, dimana Tamsulosin dengan kerjanya merelaksasi otot polos dan Dutasteride dengan kerjanya menekan DHT (dihidrotestosteron) sehingga menurunkan volume prostat. 


\section{KESIMPULAN}

Pemberian monoterapi Tamsulosin, monoterapi Dutasteride maupun kombinasi Tamsulosin-Dutasteride efektif dapat menurunkan gejala dan meningkatkan kualitas hidup pasien BPH.Pemberian monoterapi Tamsulosin dalam penurunan rata-rata IPSS (International Prostate Symtom Score) pasien BPH adalah 1.985 ; Dutasteride adalah 0.748 ; dan kombinasi Tamsulosin-Dutasteride adalah 3.245 Pemberian monoterapi Tamsulosin dalam penurunan rata-rata kualitas hidup pasien BPH adalah 3.109 ; Dutasteride adalah 3.276 ; dan kombinasi Tamsulosin-Dutasteride adalah 2.853 sehingga peningkatan kualitas hidup terapi kombinasi lebih baik dibandingkan masing-masing monoterapi karena mempunyai nilai yang lebih kecil.Dalam terapi BPH yang memiliki efektifitas lebih baik dalam penurunan gejala dan meningkat kualitas hidupnya adalah terapi kombinasi dibandingkan monoterapi Tamsulosin maupun Dutasteride, dilihat dari nilai signifikansi yang paling kecil yaitu 0,010 .

\section{DAFTAR PUSTAKA}

Afriyani, I. (2009). Metode Penelitian Kualitatif. [e-book], Diakses tanggal 19 Oktober 2011.http://www.litbang.depkes.go.id//pdbk/wpcontent/uploads/2011/04/PenelitianK ualitatif.pdf

Learning and Development Department GSK-Indonesia. (2007). Disease \& Product Knowledge Benign Prostatic Hyperplasia.

Mansjoer Arif, Suprohaita, Ika Wardhani Ika Wahyu, Setiowulan Wiwiek (2000). Kapita Selekta Kedokteran, Edisi 2, Media Aesculaplus, Jakarta.

Maryam, S.R., Ekasari, F. M., Rosidawati, Jubaedi, A., Batubara, I. (2008). Mengenal Usia Lanjut dan Perawatannya. Salemba Medika. Jakarta.

Muttaqin, A \& Sari, K. (2011). Asuhan Keperawatan Gangguan Sistem Perkemihan. Salemba Medika. Jakarta.

Purnomo; B. Basuki. (2014). Dasar-Dasar Urologi, Ed. 3. Sagung Seto; Jakarta.

Robbins, L. S., Kumar V., Cotran S. R.(2007). Buku Ajar Patologi, Ed. 7, Vol 2.EGC: Jakarta.

Santoso, Singgih. (2015). Pengolahan Data Statistik di Era Informasi, SPSS 20. Elex Medi Komputindo, Jakarta. Saryono, Anggraeni D. M., (2010). Metodologi Penelitian Kualitatif Dalam Bidang Kesehatan, Nuha Medika: Yogyakarta.

Sjamsuhidajat, R., Jong de W. (2005). Buku Ajar Ilmu Bedah, Ed. 2. EGC; Jakarta.

Sugandi, S. (2007). Anatomi dan Fisiologi Kelenjar Prostat serta Kontrol Hormonal terhadap Fungsi Prostat. Diakses tanggal 10 Oktober 2011, dari URL: http://www.urologi.or.id

Sugiyono. (2010). Metode Penelitian Kuantitatif, Kualitatif dan R\&D. Alafabeta: Bandung.

Toto Syatori Nasehudin dan Nanang Gozali.2012. Metode Penelitian Kuantitafif. Pustaka setia. Bandung. 